\title{
Ontogeny and morphological diversity in immature mites (Part V)
}

MARUT FUANGARWORN ${ }^{1}$, ZHI-QIANG ZHANG ${ }^{2,3}$ \& ALIHAN KATLAV $^{4}$

'Department of Biology, Faculty of Science, Chulalongkorn University, Bangkok, 10330 Thailand. "=" marut.f@chula.ac.th

${ }^{2}$ Landcare Research, Private Bag 92170, Auckland, New Zealand.

"'zhangZ@landcareresearch.co.nz (1) https://orcid.org/0000-0003-4172-0592

${ }^{3}$ School of Biological Sciences, Centre for Biodiversity \& Biosecurity, The University of Auckland, Auckland, New Zealand

${ }^{4}$ Hawkesbury Institute for the Environment, Western Sydney University, G55, R2, Hawkesbury Campus, Locked Bag 1797, Penrith,

NSW 2751, Australia; "

4 Ontogeny and morphological diversity in immature mites: Preface to Part $\mathrm{V}$ with a summary of contributions so far

ZHI-QIANG ZHANG

$7 \quad$ Morphological ontogeny of Neoseiulus zwoelferi (Acari: Phytoseiidae)

BIN ZHANG, MIN MA \& QING-HAI FAN

29 Morphological ontogeny of Perlohmannia nasuta (Acari, Oribatida, Perlohmanniidae), with comments on Perlohmannia Berlese

STANISŁAW SENICZAK, OTILIA IVAN, TOMASZ MARQUARDT \& ANNA SENICZAK

49 Ontogenetic instars of Hermannia longisetosa Subías \& Shtanchaeva, 2013, with remarks on juveniles of Hermanniidae (Acari: Oribatida)

BADAMDORJ BAYARTOGTOKH, SERGEY G. ERMILOV, UMUKUSUM YA.

SHTANCHAEVA \& LUIS S. SUBÍAS

69 Ontogenetic instars of Melanozetes paramollicomus sp. nov., with remarks on morphological ontogeny of Sphaerozetinae (Acari: Oribatida: Ceratozetidae) BADAMDORJ BAYARTOGTOKH, SERGEY G. ERMILOV, UMUKUSUM YA. SHTANCHAEVA \& LUIS S. SUBÍAS

90 Morphological ontogeny of Oribatella similesuperbula (Acari: Oribatida: Oribatellidae) STANISŁAW SENICZAK, OTILIA IVAN, TOMASZ MARQUARDT \& ANNA SENICZAK

111 Morphological ontogeny and ecology of Ceratozetes parvulus (Acari: Oribatida: Ceratozetidae)

ANNA SENICZAK \& STANISŁAW SENICZAK

135 A new species of the genus Colopalpus Pritchard and Baker (Trombidiformes:

Tenuipalpidae) from China, with ontogenetic patterns in chaetotaxy

YUN XU \& FEI-PING ZHANG

157 Redescription of Panonychus caglei Mellott, 1968, with ontogenetic development

(Acari: Tetranychidae)

MOHAMED W. NEGM \& TETSUO GOTOH 